\title{
Skeletal Examination
}

National Cancer Institute

\section{Source}

National Cancer Institute. Skeletal Examination. NCI Thesaurus. Code C124598.

An assessment of the bone and cartilage structures. 